\title{
Work-Life Balance Challenges for Indian Employees: Socio-Cultural Implications and Strategies
}

\author{
Atasi Mohanty ${ }^{1}$, Lalatendu Kesari Jena ${ }^{2}$ \\ ${ }^{1}$ Centre for Educational Technology, IIT, Kharagpur, India \\ ${ }^{2}$ Department of Humanities and Social Sciences, IIT, Kharagpur, India \\ Email: atasim@cet.iitkgp.ernet.in, Ikjena@iitkgp.ac.in
}

Received 22 January 2016; accepted 5 March 2016; published 8 March 2016

Copyright (C) 2016 by authors and Scientific Research Publishing Inc.

This work is licensed under the Creative Commons Attribution International License (CC BY). http://creativecommons.org/licenses/by/4.0/

cc) (i) Open Access

\section{Abstract}

The changing nature at workplace coupled with changes in socio-cultural level has led to imbalance in the work and personal lives of employees all over. Increasing demand, rising awareness among women, increasing stress levels, increasing family levels etc., have made it difficult for people to cope with their work and family lives. With increasing stress levels and demands at the workplaces, attrition rate in organization is increasing. Therefore, the present day organizations are required to create a flexible environment which would help employees to manage their work and family together. This paper brings forth such issues and practices prevailing in Indian context. The materials reviewed were obtained through searches of academic, business and sociological data base containing generalized research evidence and case study findings. It includes academic journal articles, books, research reports and materials oriented to business community.

\section{Keywords}

Quality of Work, Work-Life Balance, Workplace Challenges, Socio-Cultural Aspects, Indian Professionals

\section{Introduction}

Throughout their lives, people play many roles: parents, siblings, spouse, son/daughter, friend, employee, colleague and the list go on. Most people try to handle all these roles competently and are able to cope with the demands that each role puts on them, even when these roles seemingly clash. However, work-life conflict occurs when the time and energy demands imposed by the many roles a person plays, become incompatible with one 
another. The biggest problem faced by working professionals is the inability to balance the demands and pressure at work and demands and pressures on the home front. There are two major issues that need to be understood to resolve the work-life imbalance happening among today's professionals: Role overload (RO) i.e. having too much to do and too little time to do it in limited time frame and Role interference (RI) i.e. when incompatible demands make it difficult, if not impossible, for employees to perform all their roles well. Role interference in turn consists of two factors i.e. work to family interference (WTF), where work gets the way of family life and family to work interference (FTW) where family demands (such as, child or elder care etc.) affects work [1]. However, achieving work-life balance may be a priority and desire of an individual employee; however, it is not his or her sole responsibility to be a lone fighter. Employers being the advocates of setting norms and conditions at workplace are considered to be the facilitators of work-life balance.

The contemporary India is witnessing deterioration in quality of home and community life amongst urbanites. Work-life balance as a concept has got considerable attention and as a campaign has been practiced in various organizations in the form of policy and strategy. However, many of their HR policy makers are not sure about what should constitute an ideal work-life balance program. In this context, it is observed that some organizations provide a bundle of policies and programs such as alternative work arrangements; leave policies, childcare centers while some others provide gymnasiums and recreation/sports facilities at workplace in the name of worklife balance programs. Since, employee work-life balance as a concept has got recognition from employers and HR managers in India only in the recent years, the organizational initiatives in this regard is hardly having clarity in its policy and intent. Therefore, it is apparent to understand work-life balance and its challenges because of its practical incompleteness.

\section{Genesis of Work-Life Balance}

The specific expression "work-family balance" was first used in UK in late 1970s to define an individual's stability between work life and personal life. Over the past years there was a change in terminology from workfamily balance to present work-life balance, which acknowledges that besides family; people are occupied with multiple roles in their personal and professional life to fulfill varied goals. The revised term "work-life balance (WLB)" till date remains to be inconsistently defined. Kalliath and Brough (2008) in this connection, has mentioned that, "despite the contradiction in the definition, a large part of literature has defined work-life balance as being either the absence of work-life conflict or work-life spill over” [2]. This is predominantly influenced with less defined role with the genders creating the opportunity for more work-life spill over. Quick et al. (2004) has substantiated that the spill over effect has experienced people to suffer with apprehension about their "life issues during work hours as they feel guilty about the intrusion of their personal life on their work life, and at the same time they do experience more worry about their job during their family hours” [3]. Van Dyne et al. (1994) has noted that when a professional is able to identify their role and personal needs with organizational values and goals their attachment gets much stronger [4]. It is believed that "organizations showing concern for their employee's lives through work-life balance programs can enhance and stabilize an employee's perception about their employer in return" [5]. Work-life balance is an issue not just for individuals, but for employers, the market, the state and the society as a whole. The future workforce and consumer market of contemporary society is dependent on women bearing and parent raising children. The move from a single bread winner family model to one where both parents participate in paid employment has made it increasingly difficult to maintain the worklife balance [6]. Therefore, the issue of work-life balance has been developed out of demographic and social changes which have resulted in a more diverse workforce with different family and work models.

\section{How Quality of Work and Life Has Been Perceived by Indian Employees?}

Work-life balance is basically a kind of 'satisfaction and good functioning at work and at home with a minimum of role conflict' [7]. Researchers in India while examining the perceptions of Indian employees regarding the quality of work life at workplace have found four underlying dimensions such as 1) supportive management and favorable work environment, 2) personal growth and autonomy, 3) nature of the job, 4) stimulating opportunities and friendly co-workers. In their four factor model Rao and Mohan (2008) have found that Indian employees viewed a high-quality work life as one in which there were no negative impacts on personal life and would also exhibit an absence of inappropriate work demands [8]. Factor 1, the management support also includes an expectation for a high level of predictability in the work environment, which contradicts the finding of Hofstede 
(1980) [9] for low uncertainty avoidance countries, where (India scored lowest) one would have predicted less emphasis on predictability. In factor 2 that is personal growth and autonomy, Indian employees generally prefer a positive impact on personal life and an opportunity to develop close personal relationships while trying to achieve their career goals. However, achieving some level of personal growth may be quite related to the quality of communication in the organization. Factor 3 focuses more on the rewarding nature of the job where employees prefer adequate challenges without compromising their work values. Thus, they expect that a high quality job must pay well, has good benefits as well as provides assistance for planning one's career and exist in a work context that promotes justice and equality. Factor 4 emphasizes on the importance of stimulating opportunities and co-workers where the employees can apply their knowledge and learn new things from their co-workers. Thus, the model reveals that the aspiring Indian job entrants seek to have a high level of job security, career opportunities, personal development and reward incentives in their work environment [8].

Even though in Indian work set up work-life imbalance is an issue for the employees, they are in better control over their work and personal lives [10]. In this context, organizations have a vital role to play in promoting work-life balance. Most popular work-life strategies include family care programmes, employee-friendly benefits, flexible work arrangements, financial and wellness counselling and personal convenience services [11]. While advocating for organizational patronage Thompson (2002) has suggested for some initiatives like timebased strategies like flexi-time, part-time work etc., information-based strategies such as referral services, relocation assistance, and money-based strategies like leave with pay, child-allowance etc. [12]. Some other Indian researchers have categorized work-family conflict into three dimensions such as time, strain and behavior [13]. Rajadhayaksha \& Smitha (2004) has stated that in a dual career family, work family role conflicts and organizational role stress were not significantly different among Indian husbands and wives [14]. Organizational climate is found to have high impact on work-life conflict of both male and female workforce especially the dimension of strain and behavior such as strain on job satisfaction. Job dissatisfaction is a serious issue faced by Indian organizations today, especially the IT industries. One of the antecedents of job dissatisfaction is work-life conflict. Employees in the IT sector, especial women professionals do not stay with the same organization for many years because of excessive working hours/odd timing. Hence, in order to avoid the strain arising due to monotony, restructuring of jobs can be done to suit the individuals' skills and interests by providing some kind of stimulation, by minimizing stressful aspects an introducing growth-oriented settings, allowing employees to have control over the job and take decisions on the job with restricted authority [13].

\section{Empirical Research on Work-Family Interface in India}

Most of the Indian research in 1970s and 1980s has primarily focused on "role conflict" of educated working women who used to face the competing demands of home and paid work. However, the subsequent research in 1990s has been more critical in exploring the processes involved in work-family linkages and documented the importance of some significant mediating variables such as nature of work [15]-[17], spousal support [18] [19], child-care arrangements [20], type of family structure [21]-[23], perception of family environment [16], attitude towards wife's employment [24], extent of involvement in work or family [25] and their impact on mental health outcomes of employed women. Some strong predictors of work-family conflict have emerged like lack of clarity in division of domestic responsibilities [20], lack of spousal and social support in sharing domestic responsibilities, inadequate child-care arrangements [20], and difficulties in commuting to the workplace [26].

These studies also lend support to the earlier finding that women are significantly more susceptible to the effects of work-family stress. This reveals that maximum research on work-family interface primarily concentrated only on working women and family, lacking the focus on male participation in work-family issues. However, subsequently with increasing number of urban educated working women the focus gradually shifted to dual-earner couples, father's involvement in child-care and domestic work. Some sociological research also explored the dimensions of male involvement in the work-family linkage and found mixed results such a, some studies reported high involvement of dual-earner couples in child-care [27], fathers in such families spend more quality time with their children than in single-career families [28], and some have found that husbands of women working full time experienced higher role stress and manifested more neurotic symptoms compared to those whose wives were working part-time or were full-time housewives [29].

But at the same time the changes in the family structure did not match with the changes in the spousal role. Thus, in Indian families the provider role remains primarily the central role for husbands and the nurturer role 
has been considered to be preserved for women, overlooking the importance of working wives' co-provider role in family income [30] [31]. Thus, for urban married couples, a dual-earner pattern does not necessarily imply greater share of husbands support in household work, or a greater egalitarian relationship and psychological/ emotional support. Moreover, there is a sample bias in favor of a privileged minority class as 0.005 percent of Indian population comprises working women in the organized sector/workforce [14] [32]. Hence, it has been recommended by the stalwarts (in Indian psychological research community) that it is a high time to expand research much beyond the urban educated middle-class population to get a better/larger picture of work-family conflict as experienced by India population both in organized and unorganized sector [33].

\section{Work-Family Balance Programmes in India}

Research studies related to formal equal opportunity programmes and workplace agreement in India to facilitate work and family balance especially for women workers revealed that such type of formal programmes are limited in their ability to promote work and family-friendly arrangements at workplace [34]. Rather the informal arrangements and managerial discretion remain important in realizing work and care balance. It has also been suggested that appropriate management practices or attribute changes within the workplace can make this critical juggling act/struggle more practicable [35]. In India the Equal Employment Opportunity (EEO) reporting mechanism is management focused [36]. Organizations are directed to analyze gender equality issues in their workplace and to formulate appropriate strategies [37]. During the past/last 20 years, India has moved from a regulatory system of arbitration and central wage-fixing, resulting in federal and state awards (minimum pay \& conditions/provisions across industry), to a system of decentralized agreement making between workers (Both unionized \& non-unionized) and management [38]. Moreover, the Indian industrial relations system has become extremely complex since the varieties of instruments and agreement making processes that are available have proliferated [39]. The existing legislations in this regard protect individuals from overt discrimination, but the scope for formal equal opportunity programmes in India to ensure a sustainable work-life balance especially for women workforce still remains limited [34].

Workplace culture and support is important in ensuring that women have or feel that they have access to such formal EEO programmes [35]. Very often, access to arrangements which reduce the work-life tension for women with caring responsibilities is provided in an ad-hoc basis or informal way, or negotiated outside both statutory obligations and union-negotiated agreements. Exchanges in hours or shifts work were widely accepted as mutually beneficial for women employees [34]. However, negotiating to balance individual work and care demands becomes heavily dependent on the goodwill of managers and the economic circumstances of specific workplaces. Government can support work and family reconciliations through supporting programme/s and policies that apply to all types of workers and are independent of workplace size or profitability. Programmes beyond the workplace such as funded childcare, provisions of crèche at the workplace, healthcare and counseling centers etc. are likely to be more effective in these contexts both for male and female employees. Thus, there is an urgent need for the organizations to develop policies and practices that provide support for the demands of both work and families.

A cross-cultural study of the work-family interface in 46 countries [40] confirms that work-family conflict is more strongly (and negatively) related to work-family fit than is family-work conflict. Across the cultural groups work is being thought of as detrimental to family as that family is being thought of as detrimental to work. This study further states that even though load of daily domestic responsibilities among male population has been increasing, is still less than women's responsibilities [41]. Thus, men's domestic labors would have less effect on family-work conflict. Women have reduced their time in domestic labor, but it is still greater than men's time, and thus it would have more effect on family-work conflict. Moreover, work-family conflict reduced the sense of work-family fit substantially more for female than for male employees. Generally women experience more family-work conflict than men and conflict is more salient feature of their work lives than it is for men. Hence, conflict is more potent in reducing women's sense of being able to manage the demands of work and family life. Having a supportive partner/spouse may contribute to reduced family-to-work conflict, at least for women in the West and East, but not for women in developing nations. Furthermore, a micro level analysis highlights the fact that cultural, social and public policy contexts affect the way workplaces respond to working parents and how work and family demands and supports are experienced by individual workers [42]. This cross-cultural examination of workplace and government policies can be a critical learning point for policy makers to introduce cer- 
tain strategies like job flexibilities in location and timing and find some culturally appropriate ways to alleviate the harmful effects of high level of work-family conflict.

\section{Strategic HR Initiatives for Achieving Work-Life Balance}

Achieving work-life balance is a pride possession of a professional; however this is not a sole responsibility of him. Employers being the advocates of setting the norms and conditions at workplace are considered to be the facilitators of employee work-life balance. Osterman, (1995) has stated work-life balance programs as, "institutionalized structural and procedural arrangements, as well as formal and informal practices that makes it easier for individuals to manage conflicting worlds of work and family lives” [43]. Employers can plan their work-life balance programs in three major categories: policies, benefits and services. Policies cover the formal and informal ways by which employee's work and leave schedules are handled, including part-time work, flexi-time and parental/family leave. Benefits cover forms of compensation that protect against loss of earnings, payment of medical expenses and sponsoring a vacation. Services include on-site or near-site childcare centers, medical facilities and counseling [44]. They have stated that, keeping the changing scenario in mind, present day organizations are just not restricting themselves to the mandatory welfare practices stipulated by law, but they are becoming more conscious towards the need and growth of their employees, their families and society as a whole. Analysis of interview with some of the Indian HR managers working in manufacturing, IT and Telecom sectors in India have said that the MNCs have come up with initiatives to offer provisions such as flexi-time, paid paternity leave, childcare facilities and tools such as video conferencing to reduce commuting to office. At the same time, there are a handful of establishment's inspite of recognizing the productive benefits about work-life balance programs have not taken any formal initiatives. The slow and differential HR policy response in India as compared to western countries can be attributed to the political ideologies, slow pace of change in socio-demographic structure, attitude of employers and lack of empirical studies showing the impact of such initiative in organizational performance [44]. Nevertheless, the range of work-life balance programs varies across organizations and adoption and effective utilization of such provisions are contingent on many cultural, organizational and individual factors. There is still a long way to go when work-life balance programs will become strategic HR initiatives in most organizations.

\section{Conclusion}

Understanding the work and personal life are not two independent spheres of life and that the debate on worklife integration involves employers and working families and understanding their available work-life options. Building an organizational culture that supports through changing the way people think and talk about their work-life balance so that using flexible working options and other work-life initiatives becomes accepted and normal for everyone regardless of their gender, seniority within the organization or personal commitments. Work-life balance practices are seen as employee friendly and socially desirable strategies of a progressive establishment. Therefore, such kind of practices should be considered at par with other strategic HR interventions at future workplaces. However, more empirical research inputs are required to formulate and implement effective human resource strategies for better adaptation and work-life balance of Indian professionals in their respective job set-ups.

\section{References}

[1] Patwardhan, N.C. (2014) Work-Life Balance Initiations for Women Employees in the IT Industry. In: Verma, P. and Shah, H., Eds., Work-life Balance: A Global Perspective, Wisdom Publications, Delhi.

[2] Kalliath, T. and Brough, P. (2008) Work-Life Balance: A Review of the Meaning of the Balance Construct. Journal of Management and Organization, 14, 323-327.

[3] Quick, J.D., Henley, A.B. and Quick, J.C. (2004) The Balancing Act: At Work and at Home. Organizational Dynamics, 33, 426-438. http://dx.doi.org/10.1016/j.orgdyn.2004.09.008

[4] Van Dyne, L., Graham, J. and Dienesch, R. (1994) Organizational Citizenship Behavior: Construct Redefinition, Measurement, and Validation. Academy of Management Journal, 37, 765-780. http://dx.doi.org/10.2307/256600

[5] Grover, S. and Crooker, K. (1995) Who Appreciates Family-Responsive Human Resource Policies: The Impact of Family-Friendly Policies on the Organizational Attachment of Parents and Non Parents. Personnel Psychology, 48, 271-288. http://dx.doi.org/10.1111/j.1744-6570.1995.tb01757.x 
[6] McPherson, M. (2007) Work-Life Balance, Employee Engagement and Discretionary Effort: A Review of the Evidence. http://www.eeotrust.org.nz/content/docs/reports/Employee\%20Engagement\%202007\%20Report.doc

[7] Clark, S. (2000) Work-Family Border Theory: A New Theory of Work-Life Balance. Human Relations, 53, 747-770. http://dx.doi.org/10.1177/0018726700536001

[8] Rao, P.K. and Mohan, A.C. (2008) Perceptual Factors in Quality of Work-Life of Indian Employees. Management and Labour Studies, 33, 373-383. http://dx.doi.org/10.1177/0258042X0803300304

[9] Hofstede, G. (1980) Culture \& Consequences. Beverly Hills, Sage.

[10] Gunarathy, J.S. and Thenmozhi, R. (2009) Decision Latitude, Psychological Job, Demands and Work-Life Imbalance-A Study among Software Professionals. Management and Labor Studies, 34, 315-328. http://dx.doi.org/10.1177/0258042X0903400301

[11] Hacker, S.K. and Doolen, T.L. (2003) Strategies for Living: Moving from the Balance Paradigm. Career Development International, 8, 283-290. http://dx.doi.org/10.1108/13620430310496099

[12] Thompson, C.A. (2002) Managing the Work-Life Balancing Act: An Introductory Exercise. Journal of Management Education, 26, 205-220. http://dx.doi.org/10.1177/105256290202600206

[13] Aiswarya, B. and Ramasundaram, G. (2012) A Study on Interference of Work-Life: Conflict between Organizational Climate and Job Satisfaction of Women Employees in the Information Technology Sector. Asia-Pacific Journal of Management Research and Innovation, 8, 351-360. http://dx.doi.org/10.1177/2319510X1200800315

[14] Rajadhyaksha, U. and Smita, S. (2004) Tracing a Timeline of Work and Family Research in India. Economic and Political Weekly, 39, 1674-1680.

[15] Sharma, N.R., Yadav, A. and Yadav, A. (2001) Mental Health of Women in Relations to Job Stress. Journal of Personality and Clinical Studies, 17, 41-48.

[16] Asha, C.B. (1994) Job Satisfaction among Women in Relation to Their Family Environment. Journal of Community Guidance, 11, 43-50.

[17] Triveni, S. and Aminabhavi, V.A. (2002) Gender Difference in Occupational Stress Experience among Professional and Non-Professionals. Journal of Community Guidance and Research, 19, 1-7.

[18] Chandra, P.S., Sudha, M.B., Subbaratna, A.R. and Rao, S. (1995) Mental Health in Mothers from a Transitional Society: The Role of Spouse Supportiveness. Family Therapy, 22, 49-59.

[19] Misra, P. (1998) Predictors of Work-Family Conflict among Indian Women. Indian journal of clinical Psychology, 25, 13-19.

[20] Sahoo, F.M. and Bidyadhar, S. (1994) Work-family Linkage: An Application of Lens Model to Generate Indigenous Dimensions. Psychology and Developing Societies, 6, 169-185. http://dx.doi.org/10.1177/097133369400600206

[21] Asha, C.B. (1992) Multiple Roles and Mental Health Status of Working Women. Journal of Community Guidance and Research, 9, 181-188.

[22] Mukherjee, R. and Bakshi, M. (1996) A Comparative Study between the Nature of Job Satisfaction of Married and unmarried women in Calcutta. Indian Journal of Psychological Issues, 4(1), 14-17.

[23] Suppal, P.G., Roopnariney, J.L. and Bennet, A. (1996) Ideological beliefs about family practices: Contemporary Perspectives among North Indian Families. International Journal of Psychology, 31, 29-37. http://dx.doi.org/10.1080/002075996401197

[24] Sharma, S. and Vohra, S.S. (1998) Roles, Role Expectation and Role Strain in Couples and Patterns in Their Marital Adjustments. Journal of Research and Application in Clinical Psychology, 1, 50-64.

[25] Sahoo, F.M. and Rath, S. (2003) Self Efficacy and Well-Being in Working and Non-Working Women: The Moderating Role of Involvement. Psychology and Developing Societies, 15, 187-200. http://dx.doi.org/10.1177/097133360301500205

[26] Krishnaswamy, S. and Kulkarni, L.V. (1997) Factors Influencing Anxiety of Working Women Hostellers of Bangalore City. The Indian Journal of Social Work, 58, 1-12.

[27] Singh, S.N. and Purnia, S. (1999) Division of Childcare Liability and Fathers in Single and Dual Earner Family. Indian Journal of Psychometry and Education, 30, 103-106.

[28] Gulati, J.K. (1999) Paternal Interaction in Single and Dual Career Families. Indian Journal of Psychometry and Education, 30, 97-102.

[29] Srivasatava, A.K. (1995) Role Stress and Mental Health of the Male Partners in Dual Career Couples. Psychological Studies, 40, 11-17.

[30] Kanungo, R.N. and Mishra, S. (1988) The Bases of Involvement in Work and Family Contexts. International Journal of Psychology, 23, 267-282. http://dx.doi.org/10.1080/00207598808247765 
[31] Ramu, G.N. (1989) Women, Work and Marriage in Urban India: A Study of Dual and Single Earners Couples. Sage Publications, New Delhi.

[32] (2001) Census Survey of India. Department of Public Health, Government of India.

[33] Dalal, A.K. and Misra, G. (2002) Social Psychology in India: Evolution and Emerging Trends. In: Dalal, A.K. and Misra, G., Eds., New Directions in Indian Psychology: Social Psychology, Sage Publications, New Delhi, 19-49.

[34] Palanivel, R.V. and Sinthiya, M. (2012) Women’s Work and Family Balance: The Scope for Equal Opportunity Programme in India. South Asia Research, 32, 215-231. http://dx.doi.org/10.1177/0262728012469374

[35] Eaton, S. (2003) If You Can Use Them: Flexible Policies, Organizational Commitment and Perceived Performance. Industrial Relations, 42, 145-158. http://dx.doi.org/10.1111/1468-232x.00285

[36] Bacchi, C. (1996) The Politics of Affirmative Action. Sage Publications, London.

[37] EOWA (2007) Developing a Workplace Programme. Publications of the Equal Opportunity for Women in the Workplace Agency. http://www.eeo.gov.au/Developing_A_Workplace_Program.asp

[38] Burgess, J. and McDonald, D., Eds. (2003) Developments in Enterprise Bargaining in Australia. Tertiary Press, Melbourne.

[39] Bray, M. and Waring, P. (2005) “Complexity” and “Congruence” in Indian Industrial Relations. Journal of Industrial Relations, 47, 1-15. http://dx.doi.org/10.1111/j.1472-9296.2005.00155.x

[40] Hill, E.J., Yang, C., Hawkings, A.J. and Ferries, M. (2004) A Cross Cultural Test of the Work-Family Interface in 48 Countries. Journal of Marriage and Family, 66, 1300-1316. http://www.jstor.org/stable/3600341 http://dx.doi.org/10.1111/j.0022-2445.2004.00094.x

[41] Pleck, J.H. (1997) Paternal Involvement: Levels, Sources and Consequence. In: Lamb, M.E., Ed., The Role of the Father in Child Development, Wiley Publications, New York, 66-103.

[42] Korabik, K., Lero, D.S. and Ayman, R. (2003) A Multi-Level Approach to Cross Cultural Work-Family Research: A Micro and Macro Perspective. International Journal of Cross Cultural Management, 3, 289-303. http://dx.doi.org/10.1177/1470595803003003003

[43] Osterman, P. (1995) Work-Family Programs and the Employment Relationship. Administrative Science Quarterly, 40, 681-700. http://dx.doi.org/10.2307/2393758

[44] Baral, R. and Bhargava, S. (2010) Work Family Enrichment as a Mediator between Organizational Interventions for Work-Life Balance and Job Outcomes. Journal of Managerial Psychology, 25, 274-300. http://dx.doi.org/10.1108/02683941011023749 